\section{Wenlock-Ludlow boundary sediments on Chernov uplift (Arctic region of Russia)}

VladimiR A. MATVEEV - Institute of Geology Komi SC UB RAS, Syktyvkar " vamatveev@geo.komisc.ru

TATIANA M. BEZNOSOVA - Institute of Geology Komi SC UB RAS, Syktyvkar

- beznosova@geo.komisc.ru

LÁszLó A. GÖMZE - Institute of Ceramics and Polymer Engineering, University of Miskolc, Hungary, IGREX Engineering Service Ltd • femgomze@uni-miskolc.hu

Érkezett: 2020. 06. 30. - Received: 30. 06. 2020. - https://doi.org/10.14382/epitoanyag-jsbcm.2020.28

\section{Abstract}

The article presents the results of a study of Wenlock-Ludlow boundary sediments in the river Padimeytyvis basin at Chernov uplift using paleontological, lithological and chemostratic methods. The results of paleontological studies allowed attributing to the Wenlock the carbonate stratum of the upper part of the section along the stream Bezymjannyi and establishing Wenlock-Ludlow boundary only in the section of the river Padimeytyvis. The results of studying the isotope $\delta^{13} \mathrm{C}$ in Wenlock-Ludlow boundary sediments are also presented. In the upper part of the section along the stream Bezymyanny a positive C-isotopic shift of the curve which possibly marks the late Wenlock global biotic event of Mulde was observed.

Keywords: Ludlow, Wenlock, conodonts, brachiopods, Arctic region, Timan-Northern Ural region, isotope $\delta^{13} \mathrm{C}$

Kulcsszavak: Ludlow, Wenlock, conodonta, brachiopoda, sarkvidéki régió, Timán-Észak-Urál régió, $\delta^{13} C_{\text {arb }}$ izotóp.

\section{Introduction}

The study of the stratigraphy of the paleozoic sediments of Chernov uplift began in 1921 by the Northern Scientific and Trade Expedition where G. A. Chernov worked. The results of the study of Silurian sediments and collections of fossil fauna are given in field diaries, thematic reports and published works by G. A. Chernov [1-3], S. A. Knjazev [4], A. I. Ljashenko [5], N. I. Timonin [6], A. I. Antoshkina, T. M. Beznosova [7], T. L. Modzalevskaya [8], T. M. Beznosova [9-11], P. Mannik, V. A. Matveev [12-13], N. V. Maidl [14], V. Y. Lukin [15]. In these works, the conditions for the formation of sediments composing the section, their age are considered, and their own stratigraphic dissection schemes are proposed. Issues of stratigraphy of Wenlock deposits in the Podymeityvis River basin have been reviewed repeatedly. A variety of conclusions about the age of Wenlock-Ludlow boundary stratum in the section of Chernov uplift testifies to the complexity of its structure and biostratigraphic dissection, as shown by our subsequent detailed studies. The history of the study of Silurian strata at Chernov uplift is given in publications [9-12].

In the sections of the Mikhailov-Vaigach structural-facies zone and the Timan-Northern Ural region the Wenlock-Ludlow boundary is determined with considerable relativity since it has an indistinct paleontological and lithological characteristic [16]. According to the stratigraphic scheme of the Urals, the regional Wenlock-Ludlow boundary between in the Timan-Northern Ural region is relatively established in a lithologically homogeneous member by the appearance of the ostracods Schreckia uralensis Abush. at the base of the Padimeytyvis horizon [17].

The newly conducted studies of sedimentation conditions of Silurian sediments at Chernov uplift made it possible to substantiate
Vladimir A. MATVEEV Scientific employee in the laboratory of stratigraphy at the N.P. Yushkin institute of Geology of the Komi SC UB RAS. Main fields of his research interest are stromatolite constructions of the Silurian of the Western slope of the Urals and the Chernov uplift. He is author of more than 30 scientific papers.

Tatiana M. BEZNOSOVA Leading researcher at the laboratory of stratigraphy. Works at the N.P. Yushkin institute of Geology of the Komi SC UB RAS, Syktyvkar (Russian Federation). Main fields of her research interest are event stratigraphy, bio chemostratigraphy, systematic, paleoecology and paleobiogeography brachiopods of the late Ordovician, Silurian and early Devonian TimanNorthern Ural region. She is author of 4 books and more than 150 scientific papers.

László A. GöMZE s establisher and professor of the Department of Ceramics and Silicate Engineering in the University of Miskolc, Hungary. He is author or co-author of 2 patents, 6 books and more than 300 scientific papers. the stormy mode of sedimentation in Wenlock. A study of the collected fauna collections - the tabulate corals of brachiopods, ostracods, conodonts, vertebrates, the nature of changes in the behavior of isotope $\delta^{13} \mathrm{C}_{\text {carb }}$ served to justify the Wenlock age of the Bezymyanny section and the Wenlock-Ludlow boundary in the section of the Podymeityvis River (Fig. 1). The established total thickness of Wenlock sediments at Chernov uplift is $300 \mathrm{~m}$.

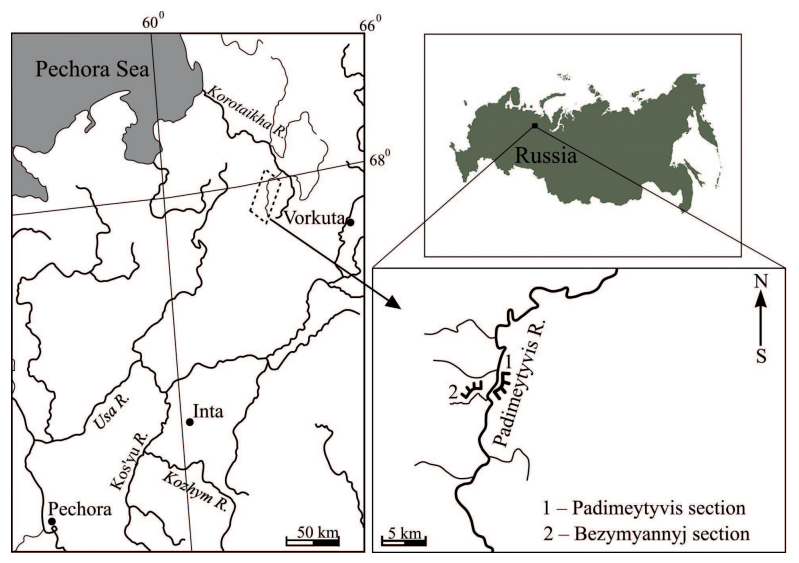

1. ábra A vizsgált szakasz földrajzi elhelyezkedése a Padimeytyvis folyó medencében Fig. 1 Scheme of the location of the studied section in the Padimeytyvis River basin

\section{Geological setting}

In the modern structural and tectonic plan, the studied section is located within the Pre-Ural foredeep in the Podymeityvis River basin at Chernov uplift (Fig. 1). It is customary to consider the Chernov uplift as a narrow near-fault horst-like structure, stretching in a sub-latitudinal direction from the Ajachyaginsky structure in the southeast to Sinkin Nose in the northwest. 
On the whole, this is a near-thrust rootless structure formed as a result of the leaf-by-leaf stripping exposure in the cover of the Korotaikhinsky depression, confined to the incompetent Upper Ordovician member $[6,18]$.

\section{Materials and methods}

The material for this article was the collections of leaf-byleaf samples collected by V. A. Matveev and P. Myannik during field work in 2010 and 2017. The collection of samples includes more than 53 samples with the remains of fossil macro- and microfauna, 44 samples for the isotope $\delta^{13} \mathrm{C}_{\text {carb }}$.

The Wenlock section is opened along the Bezymyanny stream and continues with a gap on the river Padimeytyvis (left tributary of the Korotaikha River), where the Ludlow deposits are exposed. The studied Wenlock-Ludlow sections are located in the central part of the Chernov uplift in the Arctic part of the European North-East of Russia (Fig. 1). Organic remains were investigated by: T. M. Beznosova (brachiopods), P. Mannik (conodonts), V. Y. Lukin (tabulate corals), L. L. Shamsutdinova (ostracods), P. Mannik, L. V. Sokolova (conodonts), T. Märss (vertebrates). Lithological samples were studied by T. V. Maidl, stromatolites - by V. A. Matveev. Conclusions about the age of ostracods by A. F. Abushik [19] and stromatoporoids by O. V. Bogoyavlenskaya [7] were also taken into account.

The isotope $\delta^{13} \mathrm{C}_{\text {carb }}$ in carbonate rocks was determined at the "Geoscience" of the Institute of Geology Komi SC UB RAS using a DELTA V Avantage mass spectrometer. The values of the isotope coefficients were determined in ppm (\%o) according to the PDB standards NBS18 and NBS19 (TS-limestone) for carbon. The error in determining both coefficients did not exceed \pm 0.1 $\%$. The isotope $\delta^{13} \mathrm{C}_{\text {carb }}$ was determined in 98 samples (sampling step $50 \mathrm{~cm}$ ). The material for the isotope analysis was carbonate rocks, the least subjected to secondary transformations. Samples were obtained using a diamond drill with a diameter of $3.5 \mathrm{~mm}$. Collections of fossil fauna remains are stored in the Museum named after A. A. Chernov of the Institute of Geology Komi SC UB RAS named after Academician N. P. Yushkin.

\section{Results and discussion}

The Wenlock-Ludlow boundary sediments are represented by the alternation of light brown to dark brown thin-layer limestones, platy with cracks of sediment drying, stromatolitic, clay, bioturbated limestones, containing numerous remains of ostracod shells, pelecipods, brachiopods, corals and other organisms.

The studied section thickness with a total capacity of 205 $\mathrm{m}$ was divided by us into six benches, three benches were identified along the Bezymyanny stream and three benches along the Podymeityvis River. The first five benches belong to Wenlock, the sixth bench to Ludlow (Fig. 2).

\section{Brief description of the section on the Bezymyanny stream}

Unit 1 (thickness $36 \mathrm{~m}$ ) is composed of interbedded brownish limestones and fine-grained and micrograned and limestones, dolomitic bituminous limestones, limestone with flat pebble conglomerate, ostracodic and brachiopodic limestones, which also contain fragments of trilobites, gastropods, pelicipods. Defined: brachiopods Spirinella nordensis (Ljashenko), conodonts Ozarkodina kozhimica Melnikov, Panderodus ex gr. greenlandesis Armstrong, Oulodus kozimicus Melnikov, ostracods Cytherellina aff. inornata (Abushik), Lichwinia silurica (Neckaja). The upper boundary of the bench is carried out at the base of the first layer of stromatolite limestones.

Unit II (thickness $32 \mathrm{~m}$ ) is represented by the interbedded brown, dark brown, fine-, micro-grained argillaceous limestones with silty shaly limestones, alternating with light lumpy spotted and micro-laminated microbial-algal and fenestrian limestones with leaf-by-leaf silty and argillo-dolomitic with lithoclasts and dessication fissures at different levels. A tectonic disturbance 1.8 $\mathrm{m}$ thick is observed in the lower part of the bench.

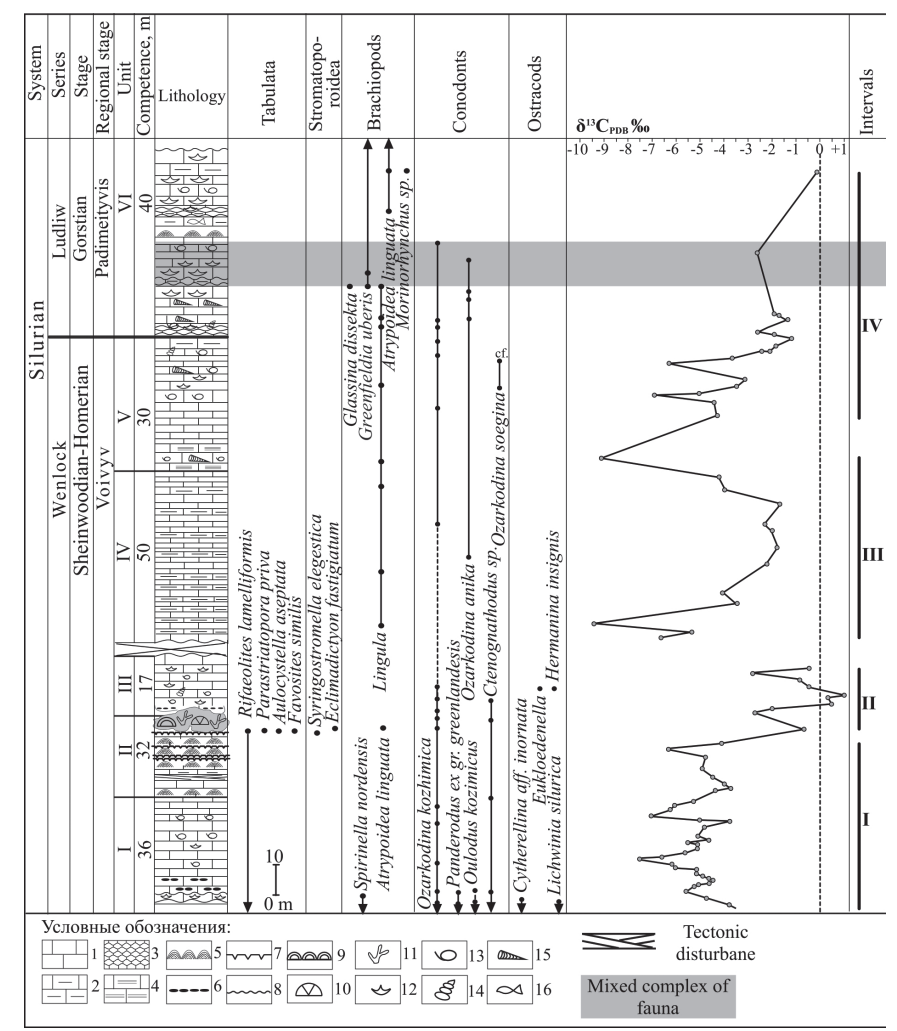

\footnotetext{
2. ábra A fauna és a $\delta^{13}$ izotópok eloszlása és a litológiai tulajdonságok a Padimeytyvis-folyó medencéjének Wenlock-Ludlow határmenti lerakódásaiban. 1-4 - mészkövek; 2 - agyagos; 3 - réteges; 5 - stromatolit; 6 lapos-kavicsos konglomerátumok; 7 - sárrepedéses; 8 - hullámjelü; 9 - stromatoporoidea; 10 - tömeges táblás; 11 - elágazó táblás; 12- kagylók; 13 - haslábúak; 14 - csigák; 15 - férgek; 16 - gerincesek

Fig. 2 Distribution of fauna, isotopes $\delta^{13} C_{\text {carb }}$ and lithological features in the Wenlock-Ludlow boundary deposits in the Padimeytyvis river basin. 1-4-limestones; 2 - clayed; 3 - laminated; 5 -stromatolitic; 6 - flat-pebble conglomerates; 7 - mud cracks; 8 - wave ripple mark; 9 - stromatoporoidea; 10 - massive tabulates; 11 - branched tabulates; 12-brachiopods; 13 - gastropods; 14 - orthoceratides; 15 - ostracods; 16 - vertebrates
}

In the bench, a stratum with organogenic structures is developed, which is represented by stromatolithic structures and coral-stromatoporate biostromes with a total thickness of 31 m (Fig. 3, A). In the lower part of this stratum, limestones with stromatolites of various morphological structures occur: bunshaped, dome-shaped and beds, reaching a diameter of $55 \mathrm{~cm}$ and a height of $25 \mathrm{~cm}$ (Fig. 3, B). Similar Wenlock stromatolite structures are known in the north of the Urals, Chernyshev uplift, Dolgyi Island and Saaremaa Island in Estonia $[8,11,15]$. 


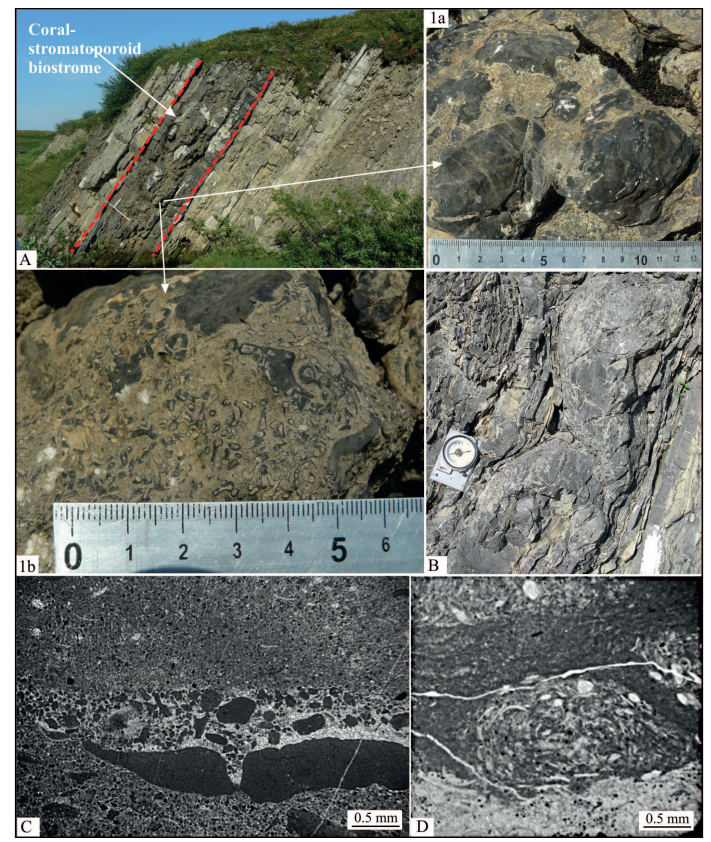

3. ábra Korall-stromatoporoid biostróma (A (II egység)); 1a - stromatoporoid kolónia; 16 - Aulocystella aseptata táblák (Barskaja, 1967); B - kupola alakú stromatolit (II. egység); C - peloid mészkö lapos belsö törmelékekkel (II. egység); D - mészkö biomorf, subrodált kaotikus viharkúp (III. egység)

Fig. 3 Coral-stromatoporoid biostrome (A (Unit II)); 1a - colony of stromatoporoid $1 b$ - tabulates Aulocystella aseptata (Barskaja, 1967); B - dome-shaped stromatolite (Unit II); C - peloid limestone with flat introclasts (Unit II), D - limestone biomorphic with subrounded chaotic storm cone (Unit III)

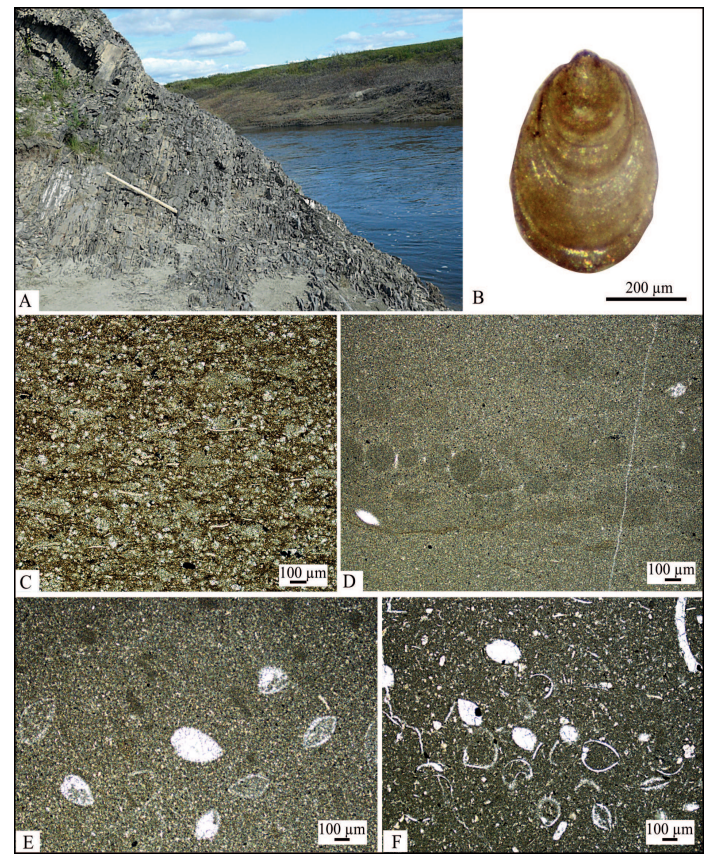

4. ábra A Wenlock-Ludlow határlerakódások a Padimeytyvis folyó szakaszán A - Wenlock mészkö a mésztartalmú pala beékelödésekkel (IV. egység); B - Lingula sp. kagylósférgek; $C$ - pelitomorf mészkö vékony bioklasztikus anyaggal (IV. egység); D - pelitomorf mészkö, bioturbált (IV. egység);

E- pelitomorf mészkö a Lingula sp. kagylók hossz- és keresztirányú héjával (V. egység); Az F-mészkő bioklasztikus-pelitomorf jellegü, csontvázaival és kagylók héjaival (V. egység).

Fig. 4 Wenlock-Ludlow boundary deposits in the section of the Padimeytyvis R iver A - Wenlock limestones with intercalations of calcareous shales (Unit IV); $B$ - brachiopod Lingula sp.; $C$ - pelitomorphic limestone with thin bioclastic material (Unit IV); D - pelitomorphic limestone, bioturbated (Unit IV); $E$-pelitomorphic limestone with longitudinal and transverse shells of the brachiopod Lingula sp (Unit V); F- limestone is bioclastic-pelitomorphic with ostracods and brachiopod shells (Unit V)
Coral-stromatoporate biostromes with stromatoporoids Syringostromella elegestica Riab., Ec. Fastigiatum (Fig. 3, 1a and 1b), tubular tabulate corals Aulocystella aseptata Barskaja and dendritic tabulate corals Riphaeolites lamelliformis Klaamann lie above.

Thin-bedded limestones with ostracods and brachiopods Atrypoidea linguata (Bush) cover the biostrom; limestones with desiccation fissures and signs of indulation ripples lie above.

A similar structure of the Upper Wenlock section gap, comprising coral-stromatoporate and stromatolite biostroms, was described by D. K. Patrunov et al. on the Dolgyi island [20]. The conodonts Ozarkodina kozhimica Melnikov, Ctenognathodus sp. are defined in the bench. The upper boundary of the bench is the biostrome roof.

Unit III (thickness $17 \mathrm{~m}$ ) is composed of brown and light brown fine- and medium-grained limestones with interbeds of limestone bioclastic, micro-layered, argillaceous. The lower part of the bench is composed of unsorted-detrital, biomorphic limestones, in which ostracods predominate, and interbeds of limestone with flatpebble conglomerate (tempestites?) (Fig. 3, C and D) and signs of undulation ripples are also observed. Brown, micro-fine-grained, aphonite limestones with interbeds of unsorted-detrital limestones, mainly ostracodic, prevail above. Brachiopods Atrypoidea linguata (Bush), ostracods Eukloedenella, Hermanina insignis Abushik., conodonts Ozarkodina kozhimica Melnikov, Ctenognathodus sp. are defined.

The lithological structure features of this part of the Wenlock section (Benches I-III) suggest that its formation occurred in open shallow shelf conditions at low sea levels, with the prevalence of storm sedimentation and the general regressive orientation of the basin development [11].

Further, after a 100-110 m break, the section continues along the Podymeityvis River.

Unit IV (thickness $50 \mathrm{~m}$ ) is composed of interbedded limestones of light brown pelitomorphic thin-bedded limestones (Fig. 4, A) containing a small amount of bioclastic material (Fig. 4, C), dark brown shaly limestones, argillaceous $(1-5 \mathrm{~cm})$ limestones and thin interbeds of calcareous argillaceous - shales. No visible fauna remains are found. When the rocks were dissolved on conodonts in the samples, the brachiopods Lingula sp. (Fig. 4, B) were found along with the conodonts of Ozarkodina kozhimica Melnikov.

Unit V (thickness $30 \mathrm{~m}$ ) is composed of interbedded limestones of light brown micro-grained, thin-bedded to shaly with light brown massive, cryptocrystalline limestones, with semi-shelly fracture, and bioturbated limestones (Fig. $4, D)$. In the bench, single shells of brachiopods, gastropods, ostracods, and orthoceratide $(1-5 \mathrm{~cm})$ were found (Fig. 4, E). Brachiopods Lingula, conodonts Ozarkodina kozhimica Melnikov, Ozarkodina anika Viira et Einasto, 2003, Ozarkodina cf. soegina Viira et Einasto, 2003 were defined.

In the roof of this bench, the contact of thin-bedded limestones to shaly and bioturbated limestones is revealed. We consider this contact as the lithological Wenlock-Ludlow boundary. The paleontological boundary was drawn along the disappearance of the inarticulate brachiopods Lingula sp. and the appearance of the Ludlow brachiopods Greenfieldia uberis and numerous ostracods (Fig 4, F). 
Unit VI (40 m thick) is composed of interbedded lumpy light brown limestones, thin-bedded limestones, dark gray bioclastic, pelitomorphic, bioturbated limestones with interbeds of dark brown shaly argillaceous. Four interbeds with stromatolithic dome-shaped structures of a diameter of $35 \mathrm{~cm}$ and a height of up to $15 \mathrm{~cm}$ are observed in the bench. On the weathered surface, it can be seen that the buildings are formed of a series of small domeshaped and columnar structures, which are intergrown at the base, of a height of $7 \mathrm{~cm}$ and a diameter of up to $6 \mathrm{~cm}$. Brachiopods G. uberis, G. dissecta, M. attenuates, Atrypoidea linguata Buch, Lingula sp., Wenlock-Ludlow conodonts Ozarkodina kozhimica, Ozarkodina soegina, Ozarkodina cf. anika (Viira et Einasto, 2003) and vertebrates Thelodus visvaldi Karatajūtè-Talimaa et Märss, 2002, are defined in the bench limestones.

\section{Biota of Wenlock-Ludlow boundary sediments}

The sea basin level increase in the late Wenlock (Sheinwudian) contributed to the taxonomic diversity of the biota. The benthic communities were based on the brachiopods represented by the Arypoidea linguata atrypids and the first in Silur sperifirids of the Spirinella nordensis, which are known in Wenlock of the Dolgy and Gotland Islands, in Great Britain, Bohemia, Mongolia, Southern China, in Llandovery and Wenlock of North America and Ludlow of Estonia. Along with brachiopods the ostracods Hermanina insignis (Abushik), Eukloedenella grandifabae Abushik, as well as gastropods, pelecipods, coral and stromatoporoid communities that formed the biostromes $[11,19]$ were developed at that time. The gradual shallowing of the basin, the development of stromatolith-forming organisms negatively affected the existence of the Spirinella brachiopods belonging to the third benthic complex (B.C. 3) and Atrypoidea belonging to B.C. 2 [21]. The increase in stromatolith interbeds observed upstream of the section, as well as desiccation fissures, indicates a progressive regression, as a result of which stromatoporoids, ostracods, pelecipods, ostracods disappeared.

Wenlock deposits (thickness about $100 \mathrm{~m}$ ), which are opened in the section along the Podymeityvis River, represented by thin-bedded, argillaceous limestones, do not contain visible fauna remains. When dissolving conodonts samples in this strata, the valves of inarticulate brachiopods Lingula belonging to B.C. 1 were defined.

Transition from Wenlock to Ludlow in the section of the river Padimeytyvis is recorded by the change of light brown, thinbedded, argillaceous limestones containing Wenlock conodonts complex and Lingula brachiopods with a depleted composition of benthic fauna to lumpy argillaceous limestones of massive appearance enclosing the Greenfieldia uberis brachiopod community. The paleontological Wenlock-Ludlow boundary is determined by the updated fauna composition (brachiopods, ostracods, vertebrates) in lumpy argillaceous limestones that compose the lower part of the Padimeytyvis Ludlow horizon. Limestones with brachiopod shells Glassina dissecta T. Modz., Morinorhynchus attenuata (Amsd.), Atrypoidea linguata (Buch), Greenfieldia uberus T. Modz. form distinct marking layers, which are traced at the Ludlow base on the Western slope of the Polar and Northern Urals, on Chernyshev uplift and numerous well sections of the Timan-Pechora oil and gas province [10].
As for the vertebrates, the remains of the vertebrates Thelodus visvaldi were discovered in the section, which until now were known only on the Severnaya Zemlya [22].

The section interval of Wenlock-Ludlow boundary sediments with a thickness of $13.7 \mathrm{~m}$ is characterized by a mixed complex of the Ludlow benthic fauna and the Wenlock complex of conodonts. In Fig. 2, this section interval is highlighted in gray. Examples of joint finds of fauna remains of different ages are known at the Llandovery-Wenlock boundary at the Chernov uplift, as well as at the Ludlow-Pridoli boundary in the section of the western slope of the Subpolar Urals $[23,24,11]$.

\section{7. $\mathrm{C}_{\text {carb }}$ Isotope Analysis}

The results of the isotope analysis, sequentially tied to the intervals of the section, showed the possibility of identifying four intervals with characteristic isotopic values that are consistent with paleontological and lithological data (Fig. 2).

Isotope characteristics of carbonates of the Wenlock-Ludlow boundary deposits in the river Padimeytyvis basin showed that in Wenlock $\delta^{13} \mathrm{C}_{\text {carb }}$ values are in the range from -9.51 to $1 \%$, and in Ludlow from -3 to $0 \%$.

In interval I, composed mainly of pelitomorphic, biolithoclastic, stromatolitic limestones, the isotope $\delta^{13} \mathrm{C}_{\text {carb }}$ is characterized by negative values. The average value of the isotope coefficient for carbon is $\delta^{13} \mathrm{C}_{\text {carb }}-5.15 \%$. Up the section, the isotope $\delta^{13} \mathrm{C}_{\text {carb }}$ has wave-like oscillations; first, the carbon values fall from -4.35 to $-7.5 \%$, which then increase to $-3.8 \%$ and fall to $-7.0 \%$.

In interval II, a sharp weighting of the isotope $\delta^{13} \mathrm{C}_{\text {carb }}$ is observed, which begins at the base of the coral-stromatoporate biostrome (bed 101) $\delta^{13} \mathrm{C}_{\text {carb }}-6.3 \ldots-0.6 \%$ and continues to the very top of the section, where it reaches maximum values $+1 \%$ (bad 109). The average isotope $\delta^{13} \mathrm{C}_{\text {carb }}$ value for this interval is $-1.18 \%$. A sharp shift of the isotope curve towards positive $\delta^{13} \mathrm{C}_{\text {carb }}$ values may correspond to the Early Wenlock biotic and isotopic Mulde event. This event is characterized by the extinction of the graptolite and conodont fauna, as well as a double positive excursion of carbon isotopes, which lies in many sections of the world [25-28].

In interval III, the average value of the isotope coefficient for carbon is $-4.48 \%$. The interval is characterized by two abnormal negative values $\delta^{13} \mathrm{C}_{\text {carb }}-9.51 \ldots-9.10 \%$.

Interval IV. The average value of the carbon isotope coefficient for this interval is $\delta^{13} \mathrm{C}_{\text {carb }}-2.98 \%$. In the lower part of the interval, two peaks of negative values of carbon isotopes $-6.29 \ldots-6.93 \%$ are recorded. Above the section, the interval is characterized by a gradual weighting of the isotope $\delta^{13} \mathrm{C}_{\text {carb }}-6.93 \ldots-0.13 \%$, which sets the trend in the positive direction of the curve.

Considering the extremely shallow deposits of the studied Wenlock-Ludlow boundary deposits, it can be assumed that the isotope-facilitated fresh water from the continent saturated with dissolved soil carbon dioxide during climate humidization periods and a corresponding increase in terrigenous runoff could influence the isotope values changes. A sharp weighting of the isotope $\delta^{13} \mathrm{C}_{\text {carb }}$ at the base of the coral-stromatoporate biostrome, unlike the lying above and below values, may indicate a change of water in the sedimentation basin from desalted to 
normal marine $[29,30]$. Such an effect is also associated with an increase in the biological productivity of the reservoir, due to warming and an increase of the sea level, which is correlated with lithological data (sequential change of layers with stromatolithic structures to coral-stromatoporate biostroms and then to limestones with diverse benthic fauna). Sharp spasmodic shifts of the isotonic curve in the studied section indicate significant changes in the characteristics of the medium of Wenlock-Ludlow boundary sedimentation in the Timan-Northern Ural Sea Basin.

\section{Conclusions}

The conducted studies supplemented the paleontological and sedimentological characteristics of Wenlock-Ludlow boundary deposits. For the first time, Wenlock-Ludlow boundary deposits received paleontological and chemostratigraphic evidence. The established thickness of Wenlock sediments at the Chernov uplift is $300 \mathrm{~m}$. Two intervals were traced in the boundary deposits in which the brachiopod communities change from benthic complex 1 in Wenlock to benthic complex 2 in Ludlow. The established anomalous excursions of carbon isotopes in the section can serve as reliable chronostratigraphic benchmarks for regional and global correlation of Wenlock sections. The results of the study confirm and complete the conclusions of G. A. Chernov on the links of the Timan-Northern Ural Sea Basin with the Baltic and Western Europe basins.

\section{Acknowledgements}

The authors are grateful to P. Mannik, who was the first to study the collection of conodonts from the Bezymyanny section at the Chernov uplift, T. Märss for determining vertebrates and L. V. Sokolova for determining the conodonts of the Padimeytvis section, L. V. Shamsutdinova for identifying ostracods of WenlockLudlow boundary sediments, N. A. Matveeva for a discussion of the results, I. V. Smoleva, an engineer at the "Geoscience", Institute of Geology Komi SC UB RAS for determining the isotope $\delta^{13} \mathrm{C}_{\text {carb }}$ in carbonate rocks, S. O. Kulikov, V. A. Radaev for helping in conducting expeditionary work.

The work was conducted within the framework of the projects ГPAAAA-A17-117121270038-1 of the Institute of Geology, Federal Research Centre Komi Scientific Centre, UB, RAS.

\section{References}

[1] Chernov, G. A. (1964): Silurian deposits of the Chernov uplift // Doklady Earth Sciences. SSSR, pp. 843-846.

[2] Chernov, G. A. (1966): Silurian stromatolites of the Chernov uplift (Bolshezemelskaya Tundra). Stratigraphy and Paleontology of North-West European Region of the USSR. Moscow, Leningrad: Nauka, pp. 90-105.

[3] Chernov, G. A. (1972): Paleozoic of the Bolshezemelskaya tundra and the prospects of its oil and gas bearing sections. Moscow: Nauka, $318 \mathrm{p}$.

[4] Knyazev, S. A. (1965): Silurian Deposits of the Central Part of the Chernov Uplift // Materials on the Geology and Minerals of Northeastern Eurasia, USSR. Syktyvkar, No. 5. pp. 112-120.

[5] Lyashenko, A. I. (1964): New species of Devonian brachiopods of the Russian platform and the Western slope of the Urals // Fauna of the Paleozoic of the Volga-Ural region of the oil and gas province. Moscow: Nauka, pp. 3-57.

[6] Timonin, N. I. (1998): Pechora Plate: History of Geological Development in the Phanerozoic. Ekaterinburg, $240 \mathrm{p}$.

[7] Antoshkina, A. I. - Beznosova T. M. (1988): New data on stratigraphy Wenlock deposits of the Bolshezmelskaya tundra. Bull. MOIP. Otdelenie geo, Vol. 63. No. 6. pp. 32-39.
[8] Modzalevskaya, T. L. (1980): Some questions of stratigraphy of Silurian deposits of the Bolshezemelskaya tundra // Annual VPO. L., Vol. 23. pp. 299-304.

[9] Beznosova, T. M. (1994): Biostratigraphy and brachiopods of the Silurian of Northeastern European Russia. St. Petersburg: Nauka. 128 p.

[10] Beznosova, T. M. (2008): Brachiopod communities and biostratigraphy of Upper Ordovician, Silurian and Lower Devonian of North-Eastern margin of Baltia paleocontinent. Ekaterinburg. 218 p.

[11] Beznosova, T. M. - Mannik, P. - Maidl', T. V. - Lukin, V. Yu. - Matveev, V. A. (2014): Depositional conditions and biota in the Llandovery-Wenlock boundary interval (Chernov uplift). Vestnik of Institute of Geology of Komi SC UB RAS, No. 3. pp. 14-18.

[12] Matveev, V. A. (2011): Wenlock stromatolitic buildups from the Chernov uplift: main morphotypes, microstructure. Vestnik of Institute of geology of Komi SC UB RAS. No. 11, pp. 2-5.

[13] Matveev, V. A. (2017): Ultrastructures of stromatolites from the Wenlock of Chernov uplift. Doklady Earth Sciences, Vol. 474, No. 2, pp. 206-209. https://doi.org/10.1134/S1028334X17050142

[14] Lukin, V. Yu. (2014): Systematic position of the species Syringoporinus aseptata Barskaja, 1967 from Silurian deposits of Chernov uplift (Bolshezemel'skaya tundra. Syktyvkarskij paleontologicheskij sbornik RAN. pp. 129.

[15] Majdl, T. V. (2013): Flat pebble conglomerates - storm sediments of the Lower Paleozoic of the Pechora sedimentary basin. Vestnik of Institute of geology of Komi SC UB RAS, No. 4, pp. 2-6.

[16] Nekhorosheva, L. V. - Patrunov, D. K. (1981): Greben' stage of the Island Vaygach-Novaya Zemlya region]. Sov. geologiya, No. 4, pp. 80-85.

[17] Explanatory note to Ural stratigraphic maps (Antsygin N.Ya. Ed) (1994): Ekaterinburg, 95 p.

[18] Yudin, V. V. (1994): Orogenesis of the Northern Urals and Pay-Khoy areas. Ekaterinburg: "Nauka", 286 p.

[19] Abushik, A. F. (2000): Silurian-Earliest Devonian ostracode biostratigraphy of the Timan - Northern Ural Region // Estonian Acad. Sci. Geol, Vol. 49, No 2. pp. 112-125.

[20] Patrunov, D. K. - Shurygina, M. V. - Cherkesova, S. V. (1980): The Silurian and Lower Devonian of the Dolgiy Island. Silurian and Lower Devonian Deposits of the Dolgiy Island. Sverdlovsk, pp. 3-26.

[21] Boucot, A. J. (1975): Community extinction and rate control. Amsterdam. P. $1-427$.

[22] Karatajute-Talimaa, V. - Märss, T. (2002): Upper Silurian thelodonts from Severnaya Zemlya Archipelago (Russia). Geodiversitas, 24 (2), pp. 405-443.

[23] Beznosova, T. M. - Matveev, V. A. - Sokolova, L. V. (2019): Upper Ludlowian-lower Pridolian stratigraphy, carbon isotope of the TimanNorthern Urals region // Építőanyag. Vol. 71, No. 1. pp. 24-37. https://doi.org/10.14382/epitoanyag-jsbcm.2019.5

[24] Kanev, Bronislav I. - Beznosova, Tatiana M. - Matveev, Vladimir A - Gömze, László A.: Environment changes at the Ludlow and Pridoli boundary (Subpolar Urals) // Építőanyag, 2017. vol. 69, no. 4. P. 132-133. https://doi.org/10.14382/epitoanyag-jsbcm.2017.24

[25] Kaljo, D. - Kiipli, T. - Martma, T. (1997): Carbon isotope event marker sthrough the Wenlock-Pridoli sequence at Ohesaare (Estonia) and Priekule (Latvia). Palaeogeography, Palaeoclimatology, Palaeoecology, 132, pp. 211-223. https://doi.org/10.1016/S0031-0182(97)00065-5

[26] Calner, M. - Eriksson, M. E. (2006): Silurian research at the crossroads. GFF 128(2), pp. 73-74. https://doi.org/10.1080/11035890601282073

[27] Cramer, B. D. - Kleffner, M. A. - Saltzman, M. R. (2006): The Late Wenlock Muldepositive carbon isotope $\left(\delta^{13} \mathrm{C}_{\text {carb }}\right)$ excursion in North America. GFF 128, pp. 85-90. https://doi.org/10.1080/11035890601282085

[28] Munnecke, A. - Calner, M. - Harper, D. A. T. - Servais, T. (2010): Ordovician and Silurian seawater chemistry, sea level, and climate: a synopsis. Palaeogeogr. Palaeoclimatol. Palaeoecol. 296, pp. 389-413. https://doi.org/10.1016/j.palaeo.2010.08.001.

[29] Yudovich, Ya. E. - Ketris, M. P. (2010): Relationships of carbon isotope in the stratosphere and biosphere: Four scenarios, Biosfera, 2010, Vol. 2, No. 2, pp. 231-246.

[30] Yudovich, Ya. E. - Ketris, M. P. (2011): Geochemical Indicators of Lithogenesis: Lithological Geochemistry), Syktyvkar: Geoprint, 742 p.

$\underline{\text { Ref.: }}$

Matveev, Vladimir A. - Beznosova, Tatiana M. - Gömze, László A.: Wenlock-Ludlow boundary sediments on Chernov uplift (Arctic region of Russia)

Építöanyag - Journal of Silicate Based and Composite Materials, Vol. 72, No. 5 (2020), 169-173. p.

https://doi.org/10.14382/epitoanyag-jsbcm.2020.28 